\title{
Use of soybean cake replacing soybean meal in diets of lambs
}

\section{Uso da torta de soja em substituição ao farelo de soja em dietas de borregos}

\author{
Elizabeth dos Santos Moura $^{1 *}$; Leandro das Dores Ferreira da Silva ${ }^{2}$; \\ Valter Harry Bumbieris Junior²; Edson Luis de Azambuja Ribeiro ${ }^{2,3}$; \\ Eduardo Lucas Terra Peixoto ${ }^{4}$; Ivone Yurika Mizubuti2,3
}

\begin{abstract}
The aim of this study was to determine the intake and digestibility, nitrogen balance and ruminal fermentation parameters in sheep fed diets containing levels of substitution of soybean meal for soybean cake. The diets consisted of five levels of protein soybean meal $(0,25,50,75$ and $100 \%)$ by soybean cake. Diets were formulated with $12.5 \% \mathrm{CP}$, respecting the forage-to-concentrate ratio of 40:60.Tifton- 85 hay was used as forage and the concentrate was formulated with corn, soybean meal, soybean cake and vitamin mineral supplement. Five crossbred lambs castrated, with average weight of $33.7 \pm 5.8 \mathrm{~kg}$ were used and distributed in a Latin Square $5 \times 5$. No differences in intake and digestibility of dry matter, organic matter, crude protein, neutral detergent fiber, total carbohydrate, nonfiber carbohydrates and total digestible nutrients. Increased linearly in ether extract intake by replacing protein from soybean meal by soybean cake in the diet but with no changes in the digestibility of this component. The nitrogen balance, nitrogen content fecal and urinary retained were not influenced by levels of substitution of soybean meal by soybeans cake in diets. For the index $\mathrm{pH}$ and concentration of ammonia nitrogen in rumen fluid did not differ between diets. It was concluded that the soybean cake can be used as an alternative food to replace soybean meal up to $100 \%$ unless there are changes in the rumen parameters, balance of nitrogen, intake and nutrient digestibility.
\end{abstract}

Key words: Co-products, oilseed, ether extract, ruminants

\section{Resumo}

Objetivou-se no presente estudo, determinar o consumo e digestibilidade dos componentes nutritivos, balanço de nitrogênio e parâmetros de fermentação ruminal em borregos alimentados com dietas contendo diferentes teores de substituição do farelo de soja pela torta de soja. Foram avaliadas uma ração testemunha (sem torta de soja) e quatro teores de substituição do farelo de soja (FS) pela torta de soja de 25; 50; 75 e 100\%. As dietas foram formuladas para conter $125 \mathrm{~g} \mathrm{~PB}$. $\mathrm{kg}^{-1} \mathrm{MS}$ na ração, respeitando-se relação volumoso:concentrado de 40:60, tendo como fonte volumosa o feno de capim Tifton-85(Cynodon spp) e como ração concentrada suplementar foram utilizados milho, farelo de soja, torta de soja, mistura mineral e vitamínica. Foram utilizados cinco borregos sem raça definida, castrados, com peso vivo médio de 33,7 $\pm 5,8 \mathrm{~kg}$, com 8 meses de idade, distribuídos em quadrado latino 5 x 5 . Não houve diferenças nos consumos e digestibilidade de matéria seca, matéria orgânica, proteína bruta, fibra em detergente neutro, carboidratos totais, carboidratos não fibrosos e nutrientes

\footnotetext{
1 Discente do Curso de Doutorado em Ciência Animal, Universidade Estadual de Londrina, UEL, Londrina, PR, Brasil. E-mail: esmoura@zootecnista.com.br

2 Profs. Drs., Dept ${ }^{\circ}$ de Zootecnia, UEL, Londrina, PR, Brasil. E-mail: leandro@uel. br; jrbumbieris@uel.br

3 Pesquisadores CNPq. E-mail: elar@uel.br; mizubuti@uel.br

4 Prof. Dr., Faculdade Ciências Agrárias, IEDAR, UNIFESSPA, Marabá, PA, Brasil. E-mail: eltpeixoto@unifesspa.edu.br

* Author for correspondece
} 
digestíveis totais entre as rações em estudo. Houve efeito linear crescente no consumo de extrato etéreo com a substituição do farelo de soja pela torta de soja na ração, porém não houve modificações na digestibilidade desse nutriente. $\mathrm{O}$ consumo de nitrogênio, os teores de nitrogênio fecal, urinário e retidos não foram influenciados pelos teores de substituição do farelo de soja pela torta de soja nas rações. Para o pH e concentração de nitrogênio amoniacal do líquido ruminal não houve diferença entre as rações Conclui-se que a torta de soja é um alimento alternativo que pode substituir totalmente o farelo de soja em dietas para borregos sem que ocorram alterações nos parâmetros ruminais, consumo e digestibilidade.

Palavras-chave: Balanço de nitrogênio, consumo, coproduto, digestibilidade, parâmetros ruminais

\section{Introduction}

Biodiesel production in Brazil has grown on a large scale in recent years. The federal government, through the National Program for Production and Use for Biodiesel, authorized the addition of $2 \%$ of this fuel on fossil diesel oil (BRASIL, 2005), and from June 2008 this addition was increased to $3 \%$. It is estimated that from 2013, it will be necessary about 2.5 billion liters of biodiesel in compliance with Law 11097/2005, because the addition of biodiesel to diesel oil was increased to $7 \%$ from November 2014.

During mechanical pressing of oilseeds, large part of oil is extracted for food production, biodiesel or lubricants, and together, there is obtained a solid residue, commonly called cake. The cakes of oilseeds are rich solid masses in lignocellulosic material, proteins, amino acids and lipids. The production of cakes from the oilseeds corresponding to the biodiesel produced in 2008 was estimated to be $3,676,566$ tons (t) (total), being the production by oilseed of: 3,261,316 t of soybeans, $318240 \mathrm{t}$ cotton, $61,200 \mathrm{t}$ of palm oil, 3,182 $\mathrm{t}$ of castor and sunflower 12629 t (STORCK BIODIESEL, 2013).

With the massive amount of by-products generated is necessary to an appropriate destination so there is a reduction of environmental pollution generated by them. The most common destinations are: sources for organic fertilizers, landfills, power generation and source of food for ruminants. Amongst these destinations deserves mention the last one because, from a product low value added is able generates noble products (meat, milk, wool, leather), associated with the fact add value to the biodiesel industry by-products, originated from oilseed extraction.

The bromatological composition of the cakes is very heterogeneous, it depends on the variety planted, harvest, pressing method. The high ether extract content can be a benefit for ruminants, whereas including of oil in the diet may help in mitigating methane enteric (MLAY et al., 2003; KUMAR et al., 2007; GRAINGER, 2008).

Thus, aimed with this study was to evaluate the intake and digestibility of the nutritional components, nitrogen balance and ruminal metabolism in lambs fed diets with different substitution levels of soybean meal by soybean cake.

\section{Material and Methods}

The experiment was carried on the premises of the animal production sector at the Farm School belonging to the Londrina State University (UEL).

Five lambs undefined breed, castrated, with average live weight of $33.7 \pm 5.8 \mathrm{~kg}$ were housed in cages with leaky floor with $1.80 \mathrm{~m}^{2}$ of floor area with individual feeders and waterers for the metabolism trial. For total feces collection, collector bags were used. The animals were weighed at the beginning and end of each evaluation period for adjustment of diets. Each trial period lasted 15 days, the first ten days were for diet adaptation. Experimental animals were submitted to the pre-experimental period (approximately 15 days) for adaptation to the metabolism cage, routine handling and feeding. 
Diets were given as a whole mixture twice a day at 7:30 a.m. and 4:30 p.m. to minimize feed loss by animals.

Were evaluated a control diet (without soybean cake) and four levels 25; 50; 75 and 100\% soybean meal replacement by soybean cake. The experimental periods were 15 days duration, with 10 days of adaptation diets with five days of sample collection carried out in the period between the 11th and 15th day. Experimental animals were submitted to the pre-experimental period (approximately 15 days) for adaptation to the metabolism cage, routine handling and feeding.

All diets were kept at a forage to concentrate ratio of 40:60, where the source of forage was hay Tifton-85 (Cynodon spp) and the concentrate ration sources were, corn, soybean meal, soybean cake, vitamin and mineral mixture (Table 1). Before preparation of rations were added antioxidant (BHT) in soybean cake to prevent lipid oxidation. The rations were given as total mixture in order to minimize the selection for the animals.

Table 1. Composition chemical-bromatological average ( $\mathrm{g} \mathrm{kg}^{-1}$ of dry matter) of the food used in the experiment.

\begin{tabular}{lcccc}
\hline Components & Tifton 85 hay & Ground corn & Soybean meal & Soybean cake \\
\hline $\mathrm{DM}^{1}$ & 868.7 & 858.2 & 873.6 & 886.0 \\
$\mathrm{OM}^{2}$ & 877.3 & 983.4 & 938.8 & 940.4 \\
$\mathrm{CP}^{3}$ & 84.5 & 106.8 & 506.5 & 464.8 \\
$\mathrm{EE}^{4}$ & 11.3 & 32.5 & 18.0 & 79.8 \\
$\mathrm{NDF}^{5}$ & 740.9 & 191.6 & 178.1 & 158.9 \\
$\mathrm{ADF}^{6}$ & 341.1 & 37.9 & 79.7 & 84.1 \\
$\mathrm{CEL}^{7}$ & 173.1 & 20.6 & 43.7 & 48.0 \\
$\mathrm{LIG}^{8}$ & 78.6 & 6.1 & 15.0 & 13.7 \\
$\mathrm{TC}^{9}$ & 781.5 & 844.1 & 414.3 & 395.8 \\
$\mathrm{NFC}^{10}$ & 40.6 & 652.5 & 236.1 & 236.9 \\
\hline
\end{tabular}

${ }^{1}$ dry matter; ${ }^{2}$ organic matter; ${ }^{3}$ crude protein; ${ }^{4}$ ether extract; ${ }^{5}$ neutral detergent fiber; ${ }^{6}$ acid detergent fiber; ${ }^{7}$ cellulose; ${ }^{8}$ lignin; ${ }^{9}$ total carbohydrates; ${ }^{10}$ non-fiber carbohydrates.

Source: Elaboration of the authors.

The animals were weighed at the beginning and end of each evaluation period for adjustment of diets. Each trial period lasted 15 days, the first ten days were for diet adaptation. Diets were formulated to be isonitrogenous with $125 \mathrm{~g} \mathrm{CP} \mathrm{kg}^{-1}$ dry matter bases (Table 2) and were increased by $10 \%$ to the requirements according to the NRC (2007).

The weighing of food offered and orts was performed daily, and data collected regarding the feeding portions for each animal during each trial period were later analyzed. Offered food and orts, as well as feces and urine, were sampled from the 11 th up to 14 th day of each trial period to determine intake, nutrient digestibility and nitrogen balance. Solid samples (supplied diet, orts and feces) were placed in plastic bags, identified, and frozen at a temperature of $-18^{\circ} \mathrm{C}$ immediately after collection. At the end of the experimental period, the samples were defrosted and dried in forced air ovens at a temperature of $55^{\circ} \mathrm{C}$ for 72 hours. Subsequently, they were milled in a Willey-type mill with a sieve of $1 \mathrm{~mm}$.

Chemical composition was identified using the methodology described by AOAC (1990) cited by Mizubuti et al. (2009) for determining the content of dry matter (DM), crude protein (CP), ether extract (EE), ash. Neutral detergent fiber (NDF), acid detergent fiber (ADF) and lignin were determinate by methodology described by Van Soest (1967) whit adaptations proposed by Detmann et al. 
(2012). Total carbohydrates (TCH) contents were calculated according to the equation proposed by Sniffen, O’Connor and Van Soest. (1992): \% \%CH =
$1000-(\mathrm{CP}+\mathrm{E}+\mathrm{ash})$. The nonfibrous carbohydrate (NFC) content was calculated using the difference between TCH and NDF.

Table 2. Formula and chemical composition of rations for lambs containing inclusion levels of soybean meal by soybean cake.

\begin{tabular}{lccccc}
\hline \multirow{2}{*}{ Feeds } & \multicolumn{5}{c}{ Levels of soybean cake $(\%)^{11}$} \\
\cline { 2 - 6 } & 0 & 25 & 50 & 75 & 100 \\
\hline Tifton 85 hay $\left(\mathrm{g} \mathrm{kg}^{-1} \mathrm{DM}\right)$ & 400.0 & 400.0 & 400.0 & 400.0 & 400.0 \\
Ground corn $\left(\mathrm{g} \mathrm{kg}^{-1} \mathrm{DM}\right)$ & 501.1 & 497.8 & 494.3 & 490.3 & 486.0 \\
Soybean meal $\left(\mathrm{g} \mathrm{kg}^{-1} \mathrm{DM}\right)$ & 73.9 & 57.9 & 40.4 & 21.2 & 0.0 \\
Soybean cake $\left(\mathrm{g} \mathrm{kg}^{-1} \mathrm{DM}\right)$ & 0.0 & 19.3 & 40.4 & 63.5 & 89.0 \\
Mineral and vitaminic mixture $\left(\mathrm{g} \mathrm{kg}^{-1} \mathrm{DM}\right)$ & 25.0 & 25.0 & 25.0 & 25.0 & 25.0 \\
\hline Total & 1000.0 & 1000.0 & 1000.0 & 1000.0 & 1000.0 \\
\hline Chemical composition & & & & & \\
\hline $\mathrm{DM}^{1}\left(\mathrm{~g} \mathrm{~kg}^{-1}\right)$ & 842.1 & 842.4 & 842.7 & 843.0 & 843.4 \\
$\mathrm{OM}^{2}\left(\mathrm{~g} \mathrm{~kg}^{-1} \mathrm{DM}\right)$ & 913.1 & 912.9 & 912.8 & 912.7 & 912.5 \\
$\mathrm{CP}^{3}\left(\mathrm{~g} \mathrm{~kg}^{-1} \mathrm{DM}\right)$ & 124.7 & 125.3 & 125.8 & 126.4 & 127.1 \\
$\mathrm{EE}^{4}\left(\mathrm{~g} \mathrm{~kg}^{-1} \mathrm{DM}\right)$ & 22.1 & 23.3 & 24.5 & 25.9 & 27.4 \\
$\mathrm{NDF}^{5}\left(\mathrm{~g} \mathrm{~kg}^{-1} \mathrm{DM}\right)$ & 405.5 & 405.1 & 404.7 & 404.2 & 403.6 \\
$\mathrm{ADF}^{6}\left(\mathrm{~g} \mathrm{~kg}^{-1} \mathrm{DM}\right)$ & 161.3 & 161.5 & 161.8 & 162.1 & 162.4 \\
$\mathrm{CEL}^{7}\left(\mathrm{~g} \mathrm{~kg}^{-1} \mathrm{DM}\right)$ & 82.8 & 83.0 & 83.1 & 83.3 & 83.5 \\
$\mathrm{LIG}^{8}\left(\mathrm{~g} \mathrm{~kg}^{-1} \mathrm{DM}\right)$ & 35.6 & 35.6 & 35.6 & 35.6 & 35.6 \\
$\mathrm{TC}^{9}\left(\mathrm{~g} \mathrm{~kg}^{-1} \mathrm{DM}\right)$ & 766.2 & 764.4 & 762.5 & 760.4 & 758.0 \\
$\mathrm{NFC}^{10}\left(\mathrm{~g} \mathrm{~kg}^{-1} \mathrm{DM}\right)$ & 360.7 & 359.3 & 357.8 & 356.2 & 354.4 \\
\hline
\end{tabular}

${ }^{1}$ dry matter; ${ }^{2}$ organic matter; ${ }^{3}$ crude protein; ${ }^{4}$ ether extract; ${ }^{5}$ neutral detergent fiber; ${ }^{6}$ acid detergent fiber; ${ }^{7}$ cellulose; ${ }^{8}$ lignin; ${ }^{9}$ total carbohydrates; ${ }^{10}$ non-fiber carbohydrates; ${ }^{11} 0,25,50,75,100$, respectively, replacement levels of soybean meal by soybean cake in diets.

Source: Elaboration of the authors.

The direct method was used to determine the apparent digestibility of nutrients by evaluating the nutrient content in feed samples and feces. The apparent digestibility (AD) was obtained using the equation described by Coelho da Silva and Leão (1979): $\mathrm{AD}=((\mathrm{Nf}-\mathrm{No}-\mathrm{Nfc}) /(\mathrm{Nf}-\mathrm{No}))^{*} 100$, where $\mathrm{Nf}=$ nutrient in feed $(\mathrm{g}), \mathrm{No}=$ nutrient in orts $(\mathrm{g})$, and $\mathrm{Nfc}=$ nutrient in feces $(\mathrm{g})$.

For urine collection, $25 \mathrm{~mL}$ of $1: 1 \mathrm{HCl}$ was placed in the collection containers daily between 11 and 14 days in each experimental period to prevent fermentation and ammonia losses in the urine by volatilization The total volume of urine excreted per animal was measured at intervals of 24 hours, and an aliquot corresponding to $10 \%$ of the total volume per animal was stored at $-15^{\circ} \mathrm{C}$ for later composition analysis. Nitrogen balance was calculated as the difference between the total nitrogen intake and the total nitrogen excreted in feces and urine (DECANDIA et al., 2000), which were expressed in $\mathrm{g} \mathrm{day}^{-1}, \mathrm{~g} \mathrm{~kg} \mathrm{BW}^{-0.75}$ and $\mathrm{g} \mathrm{kg}^{-1}$ of Nintake, respectively.

The total digestible nutrient (TDN) content of feedstuffs and diets were estimated according to the equation described by Sniffen, O'Connor and Van Soest. (1992) $\mathrm{TDN}=\mathrm{DCP}+2.25 \mathrm{DEE}+\mathrm{DTCH}$, where: $\mathrm{DCP}=$ digestible crude protein, $\mathrm{DEE}=$ digestible ether extract, and DTCH = digestible total carbohydrates. 
The rumen fluid was collected on the last day (15th day) of each experimental period before the morning feeding and at three and six hours after the morning feeding (ZEOULA et al., 2003) using an esophageal silicone probe connected to a vacuum pump. Approximately $100 \mathrm{~mL}$ of rumen fluid were collected from each animal. The $\mathrm{pH}$ was measured immediately after collection using a digital potentiometer. Afterwards, samples were filtered through three layers of cheesecloth, and three aliquots of $20 \mathrm{~mL}$ were taken from each sample. These samples were packed in pots containing sixteen drops of sulfuric acid (50\% $\mathrm{V} / \mathrm{V})$ and were stored at $-18^{\circ} \mathrm{C}$ for determination of the ruminal ammonia concentration $\left(\mathrm{NH}_{3}-\mathrm{N}\right)$. $\mathrm{NH}_{3}-\mathrm{N}$ concentrations in the rumen fluid samples were determined by distillation with potassium hydroxide $(2 \mathrm{~N})$, according to a technique described by Preston (1995). The color, smell and viscosity of the rumen fluid were observed immediately after collection according to the characteristics described by Bouda et al. (2000).

The experimental design was a Latin square design $(5 \times 5)$ with five levels of residual frying oil, five periods of sampling and five animals (experimental units). However, for data relating to ruminal parameters $\left(\mathrm{pH}\right.$ and $\left.\mathrm{NH}_{3}-\mathrm{N}\right)$, the experimental design was a Latin square $(5 \times 5)$ in a parcel-subdivided scheme with levels of residual oil in the parcel and the collecting times in the subparcel. Data were submitted to a normality test for distribution of errors, to a homogeneity of variance test, and subsequently, to an analysis of variance $(\alpha=0.05)$. The statistical package $\mathrm{R}$ (2013) was used to study the mean values by regression analysis, using " $t$ " test $(\alpha=0.05)$.

\section{Results and Discussion}

There were no differences $(p>0.05)$ in intake of dry matter (DM), organic matter (OM), crude protein $(\mathrm{CP})$, neutral detergent fiber (NDF), total carbohydrates (TC), non-fibrous carbohydrates (NFC) and total digestible nutrients (TDN), regardless of the express manner. (Table 3 ). This effect is due to prevalence of a hay with higher NDF content in feed, which may have diluted the effects of concentrated feed used, this fact made the rations kept near nutritional components (Table 1).

The experimental diets containing different levels of soybean cake attended the nutritional demands without limiting nutrient intake, as recommended by the NRC (2007), which proposes values of $1300 \mathrm{~g} \mathrm{day}^{-1}$ or $3.2 \%$ of body weight for the DM intake, $160 \mathrm{~g}$ day $^{-1}$ to CP intake and 860 $\mathrm{g} \mathrm{day}^{-1}$ TDN intake to lambs $40 \mathrm{~kg}$ weight, aged 8 months and an average weight gain of $250 \mathrm{~g} \mathrm{day}^{-1}$.

Similar results to those found in this study were verified by Azevedo et al. (2012) that evaluated the inclusion of Macaúba cake in sheep feeding that also found no differences in the consumption of DM, $\mathrm{OM}, \mathrm{CP}$, working with animals at the same average weight. Santos et al. (2009) worked with forage to concentrate ratio equal to used in this study, diets with different canola byproducts did not obtain differences in intake of NFC, CT and NDF, and the results are above those reported in this study, but this divergence may have been due to different age and requirements for maintenance for each category of animal.

There was linear increase effect $(p<0.05)$ in intake of (EE) with the substitution of soybean meal for the soybean cake in the diet (Table 3). Increased on intake of EE arises from the difference in the levels of this component on soybean meal and soybean cake, which caused elevation of ether extract contents in the diets (Table 2). 
Table 3. Intake of nutrients in diets for lambs with different levels replacement of soybean meal by soybean cake.

\begin{tabular}{|c|c|c|c|c|c|c|c|c|}
\hline \multirow{2}{*}{ Components } & \multicolumn{5}{|c|}{ Levels of sobybean cake $(\%)$} & \multirow{2}{*}{ Mean } & \multirow{2}{*}{ P-value } & \multirow{2}{*}{$\begin{array}{l}\text { V.C } \\
(\%)\end{array}$} \\
\hline & 0 & 25 & 50 & 75 & 100 & & & \\
\hline \multicolumn{9}{|c|}{ Intake $g$ animal $^{-1}$ day $^{-1}$} \\
\hline $\mathrm{DM}^{3}$ & 1251.5 & 1314.5 & 1279.3 & 1294.1 & 1350.4 & 1298.0 & 0.78 & 11.7 \\
\hline $\mathrm{OM}^{4}$ & 1134.1 & 1193.6 & 1157.9 & 1172.3 & 1225.9 & 1176.7 & 0.78 & 12.0 \\
\hline $\mathrm{CP}^{5}$ & 158.2 & 170.3 & 162.5 & 170.4 & 175.9 & 167.5 & 0.67 & 14.5 \\
\hline $\mathrm{EE}^{6}$ & 29.2 & 33.0 & 32.1 & 36.1 & 39.5 & A & 0.01 & 15.8 \\
\hline $\mathrm{NDF}^{7}$ & 447.2 & 464.5 & 458.5 & 476.4 & 488.6 & 467.1 & 0.80 & 14.1 \\
\hline $\mathrm{TC}^{8}$ & 946.6 & 990.3 & 963.3 & 965.7 & 1010.4 & 975.3 & 0.84 & 11.7 \\
\hline $\mathrm{NDF}^{9}$ & 499.4 & 525.8 & 504.7 & 489.3 & 521.8 & 508.2 & 0.67 & 13.0 \\
\hline $\mathrm{TDN}^{10}$ & 870.7 & 943.6 & 900.0 & 918.5 & 964.9 & 919.5 & 0.72 & 12.33 \\
\hline \multicolumn{9}{|c|}{ Intake $\%$ body weight } \\
\hline $\mathrm{DM}^{3}$ & 3.3 & 3.6 & 3.5 & 3.3 & 3.5 & 3.4 & 0.90 & 3.3 \\
\hline $\mathrm{OM}^{4}$ & 3.0 & 3.2 & 3.2 & 3.0 & 3.2 & 3.1 & 0.90 & 3.7 \\
\hline $\mathrm{CP}^{5}$ & 0.4 & 0.5 & 0.4 & 0.4 & 0.5 & 0.4 & 0.89 & 5.6 \\
\hline $\mathrm{EE}^{6}$ & 0.1 & 0.1 & 0.1 & 0.1 & 0.1 & 0.1 & 0.10 & 4.3 \\
\hline $\mathrm{NDF}^{7}$ & 1.2 & 1.3 & 1.2 & 1.2 & 1.3 & 1.2 & 0.98 & 4.8 \\
\hline $\mathrm{TC}^{8}$ & 2.5 & 2.7 & 2.6 & 2.5 & 2.6 & 2.6 & 0.89 & 3.3 \\
\hline $\mathrm{NDF}^{9}$ & 1.3 & 1.4 & 1.4 & 1.3 & 1.3 & 1.3 & 0.62 & 2.9 \\
\hline $\mathrm{TDN}^{10}$ & 2.5 & 2.7 & 2.6 & 2.6 & 2.7 & 2.6 & 0.72 & 12.33 \\
\hline \multicolumn{9}{|c|}{ Intake $\mathrm{g} \mathrm{kg}^{-1}$ body weight ${ }^{0,75}$} \\
\hline $\mathrm{DM}^{3}$ & 82.5 & 87.9 & 85.4 & 83.3 & 87.2 & 85.3 & 0.89 & 1.9 \\
\hline $\mathrm{OM}^{4}$ & 74.8 & 79.8 & 77.3 & 75.5 & 79.2 & 77.3 & 0.89 & 2.3 \\
\hline $\mathrm{CP}^{5}$ & 10.4 & 11.4 & 10.8 & 10.9 & 11.4 & 11.0 & 0.85 & 4.3 \\
\hline $\mathrm{EE}^{6}$ & 1.9 & 2.2 & 2.1 & 2.3 & 2.5 & $\mathrm{~B}$ & 0.04 & 2.9 \\
\hline $\mathrm{NDF}^{7}$ & 29.6 & 31.0 & 30.6 & 30.8 & 31.6 & 30.7 & 0.96 & 3.6 \\
\hline $\mathrm{TC}^{8}$ & 62.4 & 66.2 & 64.3 & 62.2 & 65.3 & 64.1 & 0.90 & 1.9 \\
\hline $\mathrm{NDF}^{9}$ & 32.8 & 35.2 & 33.7 & 31.4 & 33.7 & 33.4 & 0.62 & 1.4 \\
\hline $\mathrm{TDN}^{10}$ & 60.44 & 65.51 & 62.48 & 63.75 & 66.98 & 63.83 & 0.72 & 12.33 \\
\hline
\end{tabular}

${ }^{1} 0,25,50,75,100$, respectively, replacement levels of soybean meal by soybean cake in diets; ${ }^{2}$ variation coefficient; ${ }^{3} \mathrm{dry}$ matter ${ }^{4}$ organic matter; ${ }^{5}$ crude protein; ${ }^{6}$ ether extract; ${ }^{7}$ neutral detergent fiber; ${ }^{8}$ total carbohydrates; ${ }^{9}$ non-fiber carbohydrates; ${ }^{10}$ total digestible nutrients, ${ }^{\mathrm{A}} \hat{\mathrm{Y}}=29.24+0.095 \mathrm{x}\left(\mathrm{R}^{2}=0.90\right) ;{ }^{\mathrm{B}} \hat{\mathrm{Y}}=1.95+0.0055 \mathrm{x}\left(\mathrm{R}^{2}=0.88\right)$.

Source: Elaboration of the authors.

Similar results EE intake are found in the literature when oilseeds cakes were used in diets (AGY et al, 2012; BOSSA et al., 2012). Increased intake of this nutrient could indicate reduction in dry matter intake, however, this result was not observed due to the EE levels are below the critical threshold (5\% EE in diet) as shown in (Table 2). According to Palmquist and Mattos (2006), supplementation lipid upper that $5 \%$ in diet compromise the intake, by regulatory mechanisms controlling food intake being limited by the ability of ruminants to oxidize unsaturated fatty acids that are toxic to gram- positive microorganisms present in the rumen. Another factor that could affect the intake of fat is rancification during storage time, however, antioxidant (BHT) was used prior to the preparation of rations in order to prevent lipid oxidation, thereby reducing this risk.

There was no difference $(\mathrm{p}>0.05)$ for digestibility coefficients DM, OM, CP, EE, NDF, TC and NFC of diets with different levels of substitution of soybean meal by soybean cake (Table 4). The results found for the digestibility of the nutritional components is not changed due to the consumption of nutrients, 
besides being directly related to the forage source ingredients of ration, as hay also suffered process of low quality and small size of particle of the grinding.

Table 4. Digestibility coefficient of diets according to the levels of replacement of soybean meal by soybean cake.

\begin{tabular}{|c|c|c|c|c|c|c|c|c|}
\hline \multirow{2}{*}{ Components } & \multicolumn{5}{|c|}{ Levels of sobybean cake $(\%)^{1}$} & \multirow{2}{*}{ Mean } & \multirow{2}{*}{ P-value } & \multirow{2}{*}{$\begin{array}{c}\text { V.C. }^{2} \\
(\%)\end{array}$} \\
\hline & 0 & 25 & 50 & 75 & 100 & & & \\
\hline $\mathrm{DM}^{3}$ & 0.74 & 0.76 & 0.74 & 0.75 & 0.75 & 0.75 & 0.93 & 5.1 \\
\hline $\mathrm{OM}^{4}$ & 0.74 & 0.76 & 0.74 & 0.75 & 0.75 & 0.75 & 0.91 & 5.1 \\
\hline $\mathrm{CP}^{5}$ & 0.65 & 0.69 & 0.65 & 0.68 & 0.68 & 0.67 & 0.75 & 8.5 \\
\hline $\mathrm{EE}^{6}$ & 0.82 & 0.83 & 0.83 & 0.84 & 0.85 & 0.83 & 0.51 & 3.8 \\
\hline $\mathrm{NDF}^{7}$ & 0.613 & 0.63 & 0.61 & 0.62 & 0.63 & 0.62 & 0.98 & 10.8 \\
\hline $\mathrm{TC}^{8}$ & 0.75 & 0.77 & 0.75 & 0.76 & 0.76 & 0.76 & 0.95 & 5.2 \\
\hline $\mathrm{NDF}^{9}$ & 0.87 & 0.89 & 0.88 & 0.89 & 0.89 & 0.89 & 0.81 & 3.8 \\
\hline
\end{tabular}

${ }^{1} 0,25,50,75,100$, respectively, replacement levels of soybean meal by soybean cake in diets; ${ }^{2}$ variation coefficient; ${ }^{3} \mathrm{dry}$ matter ${ }^{4}$ organic matter; ${ }^{5}$ crude protein; ${ }^{6}$ ether extract; ${ }^{7}$ neutral detergent fiber; ${ }^{8}$ total carbohydrates; ${ }^{9}$ non-fiber carbohydrates.

Source: Elaboration of the authors.

The observed results are in agreement with those reported in the literature as byproducts of biodiesel industry were used in diets (SANTOS et al., 2009; COSTA et al., 2010). Is important to highlight the use of byproducts of agribusiness as cakes can affect digestibility, by having particles with small particle size, which can reduce the production of saliva, increasing the rate of passage of digesta in the gastrointestinal tract, making it difficult to adhesion of rumen bacteria to the substrates, resulting in little time to digest the food and thus lower use of nutrients by the animal (ROGÉRIO et al., 2009).

Was expected that there would be a decrease in NDF digestion, since the oil provided through the rumen can cause reduced efficiency of fibrolytic bacteria (PETIT et al., 1997). However, this was not possible, due to the low lipid content in the experimental diets (less than 3\%); with this, the negative effect of fat was minimized.

Although there was effect on lipids intake this difference was not able to change its digestibility. The apparent digestibility values for EE are in agreement with those found by Silva et al. (2007),
Oliveira et al., (2009) and Santos et al. (2010), when they work with diets containing lipid sources observed digestibility of $85.74,84.45$ and $89.23 \%$, respectively.

This result for the intake and digestibility is interesting, as well, can completely replace the conventional feed ingredients such as soybean meal by alternative products like soybean cake which contain higher calorie content and lower value added can be used both by small farmers than in the organic sheep production, since no use of chemical solvents for oil extraction.

Nitrogen intake, concentration of fecal, urinary and retained nitrogen was not affected $(\mathrm{p}>0.05)$ by the replacement levels of soybean meal by soybean cake in the diets (Table 5). Although there have been no statistical differences in diet with higher level of soybean cake replacement, $\mathrm{N}$ intake this diet was $11 \%$ higher when compared to the reference diet. Is worth mentioning that has not been verified negative nitrogen balance to any diet, which indicates that the protein intake met the protein requirements of animals. 
Table 5. Mean for intake, excretion and nitrogen of lambs fed diets with different levels of replacement at soybean meal by soybean cake.

\begin{tabular}{|c|c|c|c|c|c|c|c|c|}
\hline \multirow{2}{*}{ Variable } & \multicolumn{5}{|c|}{ Levels of sobybean cake $(\%)^{1}$} & \multirow{2}{*}{ Mean } & \multirow{2}{*}{ P-value } & \multirow{2}{*}{$\begin{array}{l}\text { V.C. }{ }^{2} \\
(\%)\end{array}$} \\
\hline & 0 & 25 & 50 & 75 & 100 & & & \\
\hline \multicolumn{9}{|c|}{ Nitrogen intake } \\
\hline $\mathrm{g} \mathrm{day}^{-1}$ & 25.3 & 27.2 & 26.0 & 27.3 & 28.1 & 26.8 & 0.67 & 12.1 \\
\hline \multicolumn{9}{|c|}{ Nitrogen fecal } \\
\hline $\mathrm{g} \mathrm{day}^{-1}$ & 8.6 & 8.2 & 8.6 & 8.7 & 8.9 & 8.6 & 0.80 & 10.3 \\
\hline $\mathrm{g} \mathrm{kg}^{-1} \mathrm{~N}_{\text {intake }}$ & 345.0 & 305.0 & 345.0 & 322.0 & 317.0 & 327.0 & 0.75 & 17.5 \\
\hline \multicolumn{9}{|c|}{ Nitrogen urine } \\
\hline $\mathrm{g} \mathrm{day}^{-1}$ & 10.3 & 9.2 & 9.4 & 10.3 & 10.5 & 10.0 & 0.89 & 26.5 \\
\hline $\mathrm{g} \mathrm{kg}^{-1} \mathrm{~N}_{\text {intake }}$ & 400.0 & 342.0 & 382.0 & 393.0 & 372.0 & 378.0 & 0.93 & 29.0 \\
\hline \multicolumn{9}{|c|}{ Nitrogen balance } \\
\hline $\mathrm{g} \mathrm{day}^{-1}$ & 6.4 & 9.8 & 8.1 & 8.3 & 8.7 & 8.3 & 0.75 & 48.1 \\
\hline $\mathrm{g} \mathrm{kg}^{-1} \mathrm{~N}_{\text {intake }}$ & 255.0 & 353.0 & 273.0 & 285.0 & 311.0 & 295.0 & 0.81 & 46.3 \\
\hline
\end{tabular}

${ }^{1} 0,25,50,75,100$, respectively, replacement levels of soybean meal by soybean cake in diets; ${ }^{2}$ variation coefficient.

Source: Elaboration of the authors.

The ratio of $\mathrm{N}_{\text {fecal }}$ and $\mathrm{N}_{\text {urine }}$ as function to the total nitrogen intake varied between $32.7 \%$ and $37.8 \%$, respectively. Zeoula et al. (2006) evaluated diets with different levels of degradable protein in the rumen and ground corn as a source of starch in sheep observed higher $\mathrm{N}$ excretion via urine in relation to fecal excretion (35.7\% vs $20.4 \%$ of $\mathrm{N}_{\text {intake }}$ respectively). According to Van Soest (1994), when the protein degradation exceeds the rate of fermentation of carbohydrates, large amounts of nitrogen compounds can be eliminated via urine. Increasing the risk of environmental damage by excretion of nitrogen compounds in the soil, which in turn can reach ground water causing eutrophication of the environment.

Through the evaluation of qualitative parameters of rumen fluid, it is noted that for all diets, were predominant brownish dark green, aromatic odor and slightly viscous (Table 6). The combination of these parameters indicates that the rumen was in normal conditions.

The above mentioned authors found average $6.2 \mathrm{pH}$ to diet containing $39 \%$ of soybean cake as a concentrate, a value different from the average found here (6.75), however the differences are due forage to concentrate ratio used and also the difference in the methods of collection of ruminal fluid. Shen et al. (2012) to compare two methods of ruminal fluid (oral-esophageal tube and rumen cannula) found higher $\mathrm{pH}$ values in the first method, because according to the authors the probe reaches the cranial sac of the rumen which is rich in saliva and buffer solutions.

There was difference $(\mathrm{p}<0.05)$ for the $\mathrm{pH}$ in the collection times. Probably the more alkaline $\mathrm{pH}$ in the rumen fluid checked before feed is related to the low amount of nutrients available to the rumen microbial metabolism at night to have little food intake during this period, together with the intense rumination activity of the animals occurred at night. According to Allen (1997), saliva is an important mechanism for removing the $\mathrm{H}^{+}$ion in ruminal solution because has higher carbonate concentration, which attached to the $\mathrm{H}^{+}$form water and $\mathrm{CO}_{2}$. On the other hand the decrease in ruminal $\mathrm{pH}$ after the beginning of feed can be explained by the increase of carbohydrates from the rations, highly fermentable in the rumen, and the consequent production of short chain fatty acids, which, with the passage of time are absorbed by the ruminal epithelium, also explaining the reduction in $\mathrm{pH}$. 
Table 6. Proportions of the predominant physical aspects, reduction time of methylene blue, $\mathrm{pH}$ and ammonia $\left(\mathrm{NH}_{3}-\mathrm{N}\right)$ in the time of collection and levels replacement soybean meal by soybean cake in diets for lambs.

\begin{tabular}{|c|c|c|c|c|c|c|}
\hline \multirow{2}{*}{ Variable } & \multicolumn{5}{|c|}{ Levels of sobybean cake $(\%)^{*}$} & \multirow{2}{*}{ Mean } \\
\hline & 0 & 25 & 50 & 75 & 100 & \\
\hline \multicolumn{7}{|c|}{ Cor } \\
\hline Brownish dark green & 0.80 & 0.80 & 0.73 & 0.73 & 0.60 & - \\
\hline Yellowish light green & 0.20 & 0.20 & 0.27 & 0.27 & 0.40 & - \\
\hline \multicolumn{7}{|c|}{ Smell } \\
\hline Aromatic & 1.00 & 0.93 & 1.00 & 0.87 & 1.00 & - \\
\hline Sour & 0.00 & 0.07 & 0.00 & 0.13 & 0.00 & - \\
\hline \multicolumn{7}{|c|}{ Viscosity } \\
\hline Slightly viscous & 1.00 & 0.93 & 1.00 & 0.87 & 1.00 & - \\
\hline Viscous & 0.00 & 0.07 & 0.00 & 0.13 & 0.00 & - \\
\hline \multicolumn{7}{|c|}{ Reduction time of methylene blue (seconds) } \\
\hline Before fedding & 108.00 & 120.00 & 96.00 & 108.00 & 108.00 & 108.00 \\
\hline $3 \mathrm{~h}$ after fedding & 84.00 & 96.00 & 84.00 & 84.00 & 72.00 & 84.00 \\
\hline $6 \mathrm{~h}$ after fedding & 84.00 & 96.00 & 108.00 & 96.00 & 96.00 & 96.00 \\
\hline Mean & 92.00 & 104.00 & 96.00 & 96.00 & 92.00 & 96.00 \\
\hline \multicolumn{7}{|c|}{$\mathrm{pH}$} \\
\hline Before fedding & 7.03 & 7.01 & 6.94 & 7.08 & 6.94 & $7.00 \mathrm{a}$ \\
\hline $3 \mathrm{~h}$ after fedding & 6.71 & 6.73 & 6.51 & 6.61 & 6.55 & $6.62 \mathrm{~b}$ \\
\hline $6 \mathrm{~h}$ after fedding & 6.62 & 6.64 & 6.54 & 6.84 & 6.49 & $6.63 \mathrm{~b}$ \\
\hline Mean & 6.79 & 6.79 & 6.67 & 6.84 & 6.66 & 6.75 \\
\hline \multicolumn{7}{|c|}{$\mathrm{NH}_{3}-\mathrm{N}$} \\
\hline Before fedding & 30.75 & 30.75 & 32.56 & 31.64 & 33.1 & 31.76 \\
\hline $3 \mathrm{~h}$ after fedding & 31.83 & 29.09 & 31.19 & 29.99 & 32.33 & 30.89 \\
\hline $6 \mathrm{~h}$ after fedding & 27.26 & 27.45 & 32.12 & 32.48 & 32.33 & 30.33 \\
\hline Mean & 29.95 & 29.10 & 31.96 & 31.37 & 32.58 & A \\
\hline
\end{tabular}

${ }^{*} 0,25,50,75,100$, respectively, replacement levels of soybean meal by soybean cake in diets ${ }^{\mathrm{A}} \hat{\mathrm{y}}=29.48+0.03 \mathrm{x}\left(\mathrm{R}^{2}=0.69\right.$, where $\mathrm{x}$ is the levels of replacing soybean meal by soybean cake $)$

Source: Elaboration of the authors.

There was no effect $(\mathrm{p}>0.05)$ of the collection time for $\mathrm{NH}_{3}-\mathrm{N}$ content (Table 6), this behavior diverges from that reported in the literature (ZEOULA et al., 2003; DOMINGUES et al., 2010; SANTOS et al., 2012). The ammonia nitrogen values $\left(\mathrm{NH}_{3}-\mathrm{N}\right)$ had positive linear behavior $(\mathrm{p}<0.05)$ (Table 6$)$ for diets containing different replacement levels of soybean meal by soybean cake, with the prediction equation $\hat{y}=29.48+0.03 x\left(R^{2}=0.69\right)$.

The $\mathrm{NH}_{3}-\mathrm{N}$ concentrations observed in the diets were above the levels considered optimal $(23.5 \mathrm{mg}$ $\mathrm{dL}^{-1}$ ) by Mehrez et al., (1977), to obtain condition to reach maximum microbial fermentation in ruminants. According to Leng (1990), in tropical conditions, the $\mathrm{NH}_{3}-\mathrm{N}$ level should be higher than
$10 \mathrm{mg} \mathrm{dL}^{-1}$ to improve ruminal digestibility of dry matter and more than $20 \mathrm{mg} \mathrm{dL}^{-1}$ for increasing the dry matter intake. However, is worth mentioning that the excess $\mathrm{NH}_{3}-\mathrm{N}$ can cause major losses of nitrogen by feces and urine (Table 5), where the daily excretion was on average $70 \%$ of all nitrogen intake. Thus it must be careful to provide diets with large amounts of protein degraded in the rumen in order to reduce the environmental impacts caused by excess nitrogen excreted into the environment.

\section{Conclusion}

The soybean cake can be used as an alternative food in the total replacement of soybean meal, 
without the occurrence of changes in ruminal fermentation, intake and digestibility of nutrients. It has the advantage, compared to soybean meal, having the highest concentration of lipid which increases the energy density of the diet.

\section{Acknowledgements}

The authors express sincere thanks $\mathrm{CNPq}$ for financing the research project.

This article was approved by the Ethics Commission on the use of animals at the Londrina State University, filed with this committee under number 60/10, process number 123/2010, this experiment was carried out in accordance with the technical standards of biosafety and ethics.

\section{References}

AGY, M. S. F. A.; OLIVEIRA, R. L.; RIBEIRO, C. V. M.; RIBEIRO, M. D.; BAGALDO, A. R.; ARAÚJO, G. G. L.; PINTO, L. F. B.; RIBEIRO, R. D. X. Sunflower cake from biodiesel production fed to crossbred Boer kids. Revista Brasileira de Zootecnia, Viçosa, MG, v. 41, n. 1, p. 123-130, 2012.

ALLEN, M. S. Relationship between fermentation acid production in the rumen and requirement for physically effective fiber. Journal Dairy Science, Champaign, v. 80, n. 7, p. 1447-1462, 1997.

ASSOCIATION OF OFFICIAL ANALYTICAL CHEMISTS - AOAC. Official methods of analysis. 15. ed. Washington: AOAC, 1990.

AZEVEDO, R. A.; RUFINO, L. M. A.; SANTOS, A. C. R.; SILVA, L. P.; BONFÁ, H. C.; DUARTE, E. R.; CASTRO, L. G. Desempenho de cordeiros alimentados com inclusão de torta de macaúba na dieta. Pesquisa Agropecuária Brasileira, Brasília, v. 47, n. 11, p. 1663 1668, nov. 2012.

BOSSA, R.; FATURI, C.; RODRIGUES, H. G. Consumo e digestibilidade aparente de dietas com diferentes níveis de inclusão de torta de coco para alimentação de ovinos. Acta Scientiarum, Maringá, v. 34, n. 1, p. 57-62, 2012.

BOUDA, J.; QUEIROZ-ROCHA, G. F.; GONZÁLEZ, F. H. D. Importância da coleta e análise de líquido ruminal e urina. In: GONZÁLES, F. H. D.; BORGES, J. B.; CECIM, M. (Ed.). Uso de provas de campo e laboratório clínico em doenças metabólicas e ruminais dos bovinos, Porto Alegre: UFRGS, 2000. p. 13-15.

BRASIL. Lei 11. 097, de 13 de janeiro de 2005. Dispõem sobre a criação do Programa Nacional de Produção e Uso de Biodiesel e sobre a adição de biodiesel ao óleo diesel. Diário Oficial [da] União, Brasília, 14 jan. 2005. Seção 1, p. 8. Disponível em: <http://www.planalto.gov. br/ccivil_03/_ato2004-2006/2005/Lei/L11097.htm>. Acesso em: 7 ago. 2013.

COELHO DA SILVA, J. F.; LEÃO, M. I. Fundamentos de nutrição dos ruminantes. Piracicaba: Editora Livroceres, 1979. $380 \mathrm{p}$.

COSTA, D. A.; FERREIRA, G. D. G.; ARAÚJO, C. V.; COLODO, J. N.; MOREIRA, G. R.; FIGUEIREDO, M. R P. Consumo e digestibilidade de dietas com níveis de torta de dendê para ovinos. Revista Brasileira de Saúde e Produção Animal, Salvador, v. 11, n. 3, p. 783-792, 2010.

DECANDIA, M.; SITZIA, M.; CABIDDU, A.; KABABYAB, D.; MOLLE, G. The use of polyethylene glycol to reduce the anti-nutritional effects of tannins in goat fed woody species. Small Ruminant Research, Amsterdam, v. 38, n. 2, p. 157-164, 2000.

DETMANN, E.; VALENTE, T. N. P.; BERCHIELLI, T. T. Avaliação de fibra insolúvel em detergente neutro e da fibra insolúvel em detergente ácido. In: DETMANN, E.; SOUSA, M. A.; VALADARES FILHO, S. C.; QUEIROZ, A. C.; BERCHIELLI, T. T.; SALIBA, E. O. S.; CABRAL, L. S.; PINA, D. S.; LADEIRA, M. M.; AZEVEDO, J. A. G. (Ed.). Métodos para análises de alimentos - Instituto Nacional de Ciência e Tecnologia de Ciência Animal. Visconde do Rio Branco: Suprema, 2012. p. 93-111.

DOMINGUES, A. R.; SILVA, L. D. F.; RIBEIRO, E. L. A.; CASTRO, V. S.; BARBOSA, M. A. A. F.; MORI, R. M.; VIEIRA, M. T. L.; SILVA, J. A. O. Consumo, parâmetros ruminais e concentração de uréia plasmática em novilhos alimentados com diferentes níveis de torta de girassol em substituição ao farelo de algodão. Semina: Ciências Agrárias, Londrina, v. 31, n. 4, p. 1059-1070, 2010.

GRAINGER, C. GIA methane: increasing fat can reduce methane emissions. GIA Newsletter. Melbourne: Department of Primary Industries, mar. 2008. 5 p.

KUMAR, R.; KAMRA, D. N.; AGARWAL, N.; CHAUDHARY, L. C. In vitro methanogenesis and fermentation of feeds containing oil seed cakes with rumen liquor of buffalo. Asian Australasian Journal of Animal Sciences, Seoul, v. 20, n. 8, p. 1196, 2007. 
LENG, R. A. Factors affecting the utilization of "poorquality" forages by ruminants particularly under tropical conditions. Nutrition Research and Review, Cambridge, v. 3, n. 3, p. 277-303, 1990.

MEHREZ, A. Z.; ØRSKOV, E. R.; McDONALD, I. Rate of rumen fermentation in relation to ammonia concentration. Brittish Journal of Nutrition, Cambridge, v. 38, n. 3, p. 437-443, 1977.

MIZUBUTI, I. Y.; PINTO, A. P.; PEREIRA, E. S.; RAMOS, B. M. O. Métodos laboratoriais de avaliação de alimentos para animais. Londrina: EDUEL, 2009. v. $1,228 \mathrm{p}$.

MLAY, P. S.; PEREKA, A. E.; WEISBJERG, M. R.; HVELPLUND, T.; MADSEN, J. Digestion and passage kinetics of fibre in mature dairy heifers maintained on poor quality hay as affected by the source and level of nitrogen supplementation. Animal feed science and technology, California, v. 109, n. 1, p. 19-33, 2003.

NATIONAL RESEARCH COUNCIL - NRC. Nutrient requirements of small ruminants: sheep, goats, cervids and new world camelids. Washington, DC: National Academy Press, 2007. 384 p.

OLIVEIRA, R. L.; BAGALDO, A. R.; LADEIRA, M. M. Fontes de lipídeos na dieta de búfalas lactantes: consumo, digestibilidade e N-uréico plasmático. Revista Brasileira de Zootecnia, Viçosa, MG, v. 38, n. 3, p. 553559, 2009.

PALMQUIST, D. L.; MATTOS, W. R. S. Metabolismo de lipídeos. In: BERCHIELLI, T. T.; PIRES, A. V.; OLIVEIRA, S. G. (Ed.). Nutrição de ruminantes. Jaboticabal: FUNEP, 2006. p. 287-310.

PETIT, H. V.; RIOUX, R.; D’OLIVEIRA, P. S.; PRADO, I. N. Performance of growing lambs fed grass silage with raw or extrused soybean or canola seeds. Canadian Journal of Animal Science, Ottawa, v. 77, n. 3, p. 455463, 1997.

PRESTON, T. R. Biological and chemical analytical methods. In. PRESTON, T. R. (Ed.). Tropical animal feeding: a manual for research workers. Rome: FAO, 1995. p. 191-264.

R DEVELOPMENT CORE TEAM. $R$ : a language and environment for statistical computing. Vienna: $\mathrm{R}$ Foundation for Statistical Computing, 2013. Available at: $<$ http://www.R-project.org>. Accessed at: 10 abr. 2013. (Referência do programa estatístico, consta no material e métodos) (REFERÊNCIA NÃO CITADA NO TEXTO)

RADOSTITS, O. M.; GAY, C. C.; BLOOD, D. C.; HINCHCLIFF, K. W. Clínica veterinária. 9. ed. Rio de Janeiro: Guanabara Koogan, 2002. 1737 p.
ROGÉRIO, M. C. P.; BORGES, I.; RODRIGUEZ, N. M.; CAMPMPOS, W. É.; SILVA, V. L.; RIBEIRO, T. P.; NEIVA, J. N. M. Dinâmica da fermentação ruminal em ovinos alimentados com rações contendo diferentes níveis de coprodutos de caju (Anacardium occidentale). Ciência Animal Brasileira, Gôiania, v. 10, n. 2, p. 355364, 2009.

SANTOS, J. W.; CABRAL, L. S.; ZERVOUDAKIS, J. T.; ABREU, J. G.; SOUZA, A. L.; PEREIRA, G. A. C.; REVERDITO, R. Farelo de arroz em dietas para ovinos. Revista Brasileira de Saúde e Produção Animal, Salvador, v. 11, n. 1, p. 193-201, 2010.

SANTOS, V. C.; EZEQUIEL, J. M. B.; MORGADO, E. S.; HOMEM JÚNIOR, A. C.; FÁVARO, V. R.; D'AUREA, A. P.; SOUZA, J. C.; BARBOSA, J. C. Influence byproducts of oleaginous on ruminal parameters and degradation of dry matter and crude protein. Arquivo Brasileiro de Medicina Veterinária e Zootecnia, Belo Horizonte, v. 64, n. 5, p. 1284-1291, 2012.

SANTOS, V. C.; EZEQUIEL, J. M. B.; OLIVEIRA, P. S. N.; GALATI, R. L.; BARBOSA, J. C. Consumo $e$ digestibilidade em ovinos alimentados com grãos e subprodutos da canola. Revista Brasileira de Saúde e Produção Animal, Salvador, v. 10, n. 1, p. 96-105, 2009.

SHEN, J. S.; CHAI, Z.; SONG, L. J.; LIU, J. X.; WU, Y. M. Insertion depth of oral stomach tubes may affect the fermentation parameters of ruminal fluid collected in dairy cows. Journal of Dairy Science, Champaign, v. 95, n 10, p. 5978-5984, 2012.

SILVA, M. M. C.; RODRIGUES, M. T.; FLORENTINO, C. A.; RODRIGUES, R. H. B.; LEÃO, M. I.; MAGALHÃES, A. C. M.; MATOS, R. S. Efeito da suplementação de lipídios sobre a digestibilidade e os parâmetros da fermentação ruminal em cabras leiteiras. Revista Brasileira de Zootecnia, Viçosa, MG, v. 36, n. 1, p. 246-256, 2007.

SNIFFEN, C. J.; O'CONNOR, J. D.; VAN SOEST, P. J. A net carbohydrate and protein system for evaluating cattle diets: carbohydrate and protein availability. Journal of Animal Science, Madison, v. 70, n. 11, p. 3562-3577, 1992.

STORCK BIODIESEL. Biodiesel: matéria-prima. Curitiba, 2013. Disponível em: <http://www.storck.com. br/index5.htm> Acessado em: 7 ago. 2013.

VAN SOEST, P. J. Development of a comprehensive system of feed analysis and its application to forages. Journal of Animal Science, Madison, v. 26, n. 1, p. 119128, 1967.

. Nutritional ecology of ruminant. $2^{\text {th }} \mathrm{ed}$. Ithaca: Cornell University, 1994. 476 p. 
ZEOUlA, L. M.; CALDAS NETO, S. F.; GERON, L. Z ZEOULA, L. M.; FERELI, F.; PRADO, I.; GERON, L. J. V.; MAEDA, E. M.; PRADO, I. N.; DIAN, P. H. M.; J. V.; CALDAS NETO, S. F.; PRADO, O.; MAEDA, JORGE, J. R. V.; MARQUES, J. A. Substituição do milho E. M. Digestibilidade e balanço de nitrogênio de rações pela farinha de varredura de mandioca (Manihot esculent, Crantz) em rações de ovinos: consumo, digestibilidade, balanços de nitrogênio e energia e parâmetros ruminais. Revista Brasileira de Zootecnia, Viçosa, MG, v. 32, n. 2, p. 491-502, 2003. com diferentes teores de proteína degradável no rúmen e milho moído como fonte de amido em ovinos. Revista Brasileira de Zootecnia, Viçosa, MG, v. 35, n. 5, p. 21792186, 2006. 